\title{
The Effects of Androgen Replacement Therapy on Glycemic Control in Case with Klinefelter Syndrome and Poorly Controlled Diabetes
}

\author{
Ayşenur Özderya, Şule Temizkan, Kadriye Aydın Tezcan
}

Department of Endocrinology and Metabolic Diseases, Kartal Dr Lütfi Kırdar Training and Research Hospital, İstanbul, Turkey

Submitted: 22.11 .2015 Accepted: 20.01.2016

Correspondence: Ayşenur Özderya Kartal Dr. Lütfi Kırdar Eğitim ve Araştırma Hast., Endokrinoloji Polikliniği, Kartal, İstanbul, Turkey E-mail: aysenur.ozderya@gmail.com

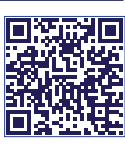

Keywords: Androgen replacement therapy; diabetes mellitus;

Klinefelter's syndrome.

\begin{abstract}
Klinefelter syndrome (KS) is the most common sex chromosome anomaly among men. It is usually characterized by hypergonadotropic hypogonadism, eunuchoid body structure, and most often, 47,XXY karyotype. Studies have shown that KS patients have high risk of developing autoimmune diseases and diabetes, and the hypogonadism that accompanies the syndrome makes regulation of diabetes more difficult. A 39-year-old man with KS was admitted to Endocrinology and Metabolic Diseases Polyclinic because of increased blood glucose level: His glycated hemoglobin ( $\mathrm{HbAlc}$ ) value was $14.9 \%$. He had diabetes for approximately 5 years and was using $80 \mathrm{IU}$ insulin daily at time of admission, but after testosterone replacement therapy, his insulin requirement decreased to 60 units. Follow-up HbAlc was $7.7 \%$ after 2 months of androgen replacement therapy. Hypoandrogenemia may contribute to development of newly diagnosed diabetes or deterioration of pre-existing diabetes. Testosterone replacement therapy can improve glycemic control in these patients.
\end{abstract}

\section{INTRODUCTION}

Klinefelter syndrome (KS) was first defined by Dr. Harry Klinefelter in 1942, and it is characterized by hypergonadotropic hypogonadism and eunuchoid body structure. ${ }^{[1]}$ Great majority of cases are diagnosed as result of infertility. Chromosome structure may have different patterns $(47, X X Y / 48$, $X X X Y / 48, X X Y Y / 49, X X X X Y$ or mosaicism); most frequently $(90 \%), 47, X X Y$ karyotype is seen. ${ }^{[2]}$ This syndrome is the most frequently encountered sex chromosome anomaly in male newborns, with an average incidence of nearly 0.2 percent. ${ }^{[3]}$ Among general characteristics of the syndrome are greater than average height, eunuchoid body structure, long arm span, scarce facial and pubic hair, small testicular volume, gynecomastia, learning disability, and personality and behavioral problems. Increase in incidence of diabetes and metabolic syndrome as result of hypogonadism have been reported in cases of KS. ${ }^{[4]}$

In this report, case of a patient who presented at outpatient clinic with complaints of polyuria and polydipsia is described. Although he was receiving intensive insulin therapy from time of diagnosis with diabetes, glycemic control had not been achieved. Investigation upon detection of regression of secondary sex characteristics revealed presence of hypergonadotropic hypogonadism. Finding of 
47, XXY karyotype on cytogenetic analysis established diagnosis of KS, and evaluation of clinical and biochemical responses following administration of androgen replacement therapy are presented.

\section{CASE REPORT}

Despite extreme attention to diet, as well as treatment that included intensive insulin $(3 \times 20 \mathrm{IU}$ insulin aspart plus Ix20 IU insulin detemir) since determination of type 2 diabetes diagnosis 5 years earlier, a 39-year-old male patient presented at outpatient clinic due to persistence of high glycemic levels. $\mathrm{Pa}$ tient was taking daily dose of $80 \mathrm{IU}(\mathrm{I} .35 \mathrm{IU} / \mathrm{kg})$ insulin and had serious symptoms of polyuria and polydipsia. His father and 2 siblings also had type 2 diabetes mellitus. Patient had been married and trying to conceive for 14 years, but was childless. $\mathrm{He}$ had previously sought medical care for infertility, but had not attended follow-up visits.

Patient was $169 \mathrm{~cm}$ tall and weighed $59 \mathrm{~kg}$. Physical examination findings included: body mass index: $21 \mathrm{~kg} / \mathrm{m}^{2}$, body temperature: $36.8^{\circ} \mathrm{C}$, arterial blood pressure: $130 / 70 \mathrm{mmHg}$, heart rate: 72 beats/ min, rhythmic. Eunuchoid body proportions (arm span: $176 \mathrm{~cm}$, distance from vertex of the head to the pubis: $80 \mathrm{~cm}$, from pubis to floor: $89 \mathrm{~cm}$ ), and regression of secondary sex characteristics (absence of facial and chest hair, Tanner stage 3-4 axillary and pubic hair, $8 \mathrm{~cm}$-long penis, below normal muscle mass, and feminine-type fat distribution) were also detected (Figure I).

Laboratory values as follows are provided in Table I: Fasting blood sugar: $421 \mathrm{mg} / \mathrm{dL}$ (range: 74-106 $\mathrm{mg} / \mathrm{dL}$ ), glycated hemoglobin ( $\mathrm{HbAlc}):$ I4.9\% (range: $4.2-6.5 \%)$, follicle-stimulating hormone (FSH): $40 \mathrm{mlU} / \mathrm{mL}$ (range: $1.4-18.1 \mathrm{mlU} / \mathrm{mL}$ ), luteinizing hormone (LH): $28.9 \mathrm{mlU} / \mathrm{mL}$ (range: $1.5-9.3 \mathrm{mIU} /$ $\mathrm{mL}$ ), total testosterone: $7 \mathrm{l} .4 \mathrm{ng} / \mathrm{dL}$ (range: $24 \mathrm{I}-$ $827 \mathrm{ng} / \mathrm{dL}$ ), sex hormone binding globulin (SHBG): $35.7 \mathrm{nmol} / \mathrm{L}$ (range: $13-7 \mid \mathrm{nmol} / \mathrm{L}$ ), and estradiol (E2): $<7 \mathrm{pg} / \mathrm{mL}$ (range: II.6-4l.2 pg/mL). These measurements were found to be consistent with hypergonadotropic hypogonadism. Furthermore, C-reactive protein (CRP) level: $1.96 \mathrm{mg} / \mathrm{L}$, white blood cell count (WBC): $7.15 \quad 10^{3} / \mathrm{mL}$, and erythrocyte sedimentation rate (ESR): $7 \mathrm{~mm} / \mathrm{h}$ were determined; there were no symptoms of infection. Karyotype analysis was consistent with $47, X X Y$ KS. Scrotal ultrasound revealed presence of int-
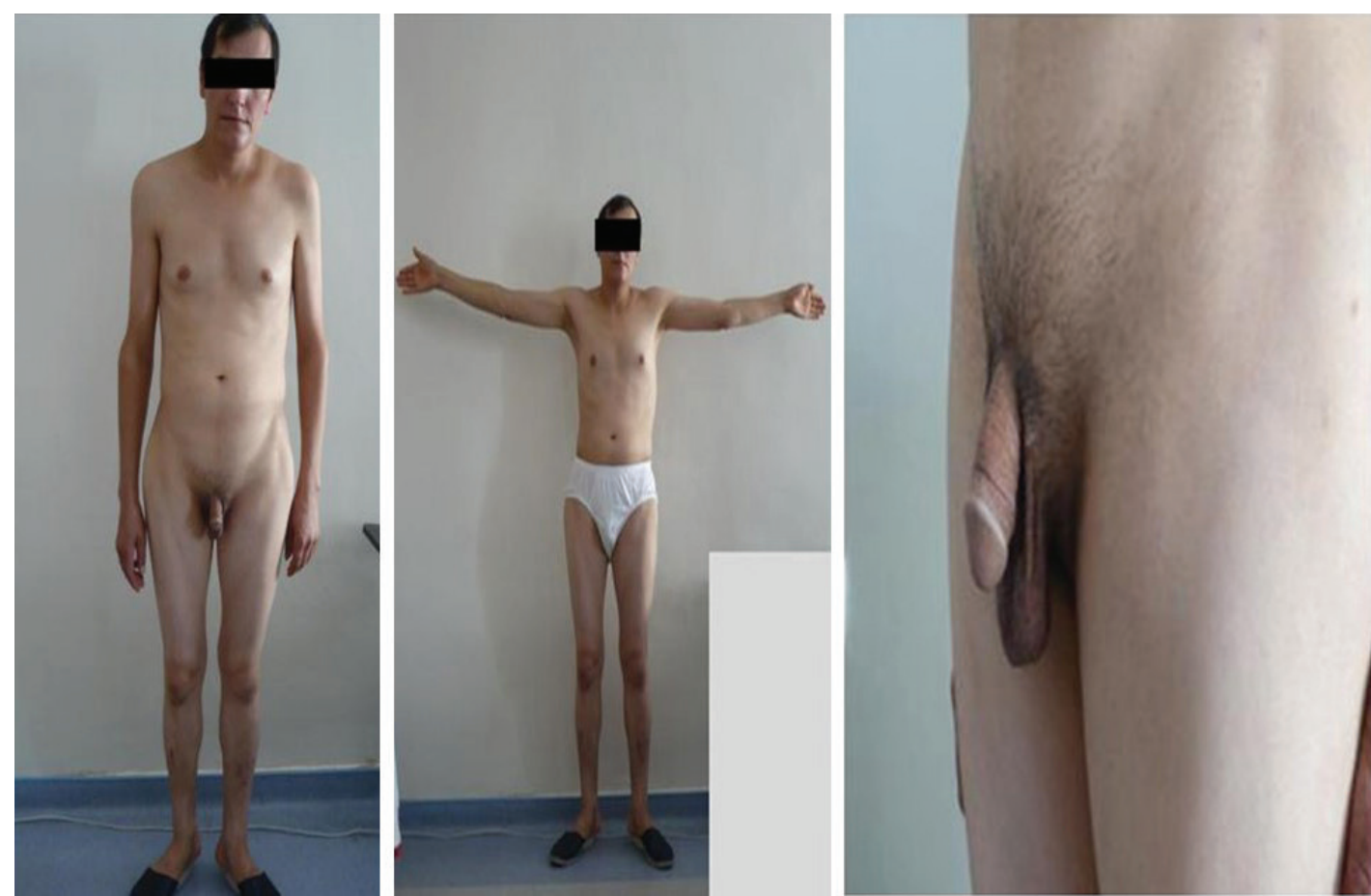

Figure 1. Patient with $47, \mathrm{XXY}$ karyotype was $169 \mathrm{~cm}$ tall, weighed $59 \mathrm{~kg}$, and was 39 years old. Body proportions were arm span of $176 \mathrm{~cm}$, distance from crown of the head to the pubis of $80 \mathrm{~cm}$, and from pubis to floor of $89 \mathrm{~cm}$. Regression of secondary sex characteristics (absence of facial and chest hair, Tanner stage 3-4 axillary and pubic hair, $8 \mathrm{~cm}$-long penis, below normal muscle mass, and feminine-type fat distribution) was also present. 
Table 1. Laboratory findings

\begin{tabular}{|c|c|c|c|c|c|}
\hline \multicolumn{2}{|l|}{ Blood biochemistry } & \multicolumn{2}{|l|}{ Hormones } & \multicolumn{2}{|l|}{ Complete blood count } \\
\hline Glucose (74-106 mg/dL) & 421 & Free T3 $(2.3-4.2 \mathrm{pg} / \mathrm{mL})$ & 3.06 & Red blood cell (4-6.2 106/uL) & 5.69 \\
\hline Urea $(17-43 \mathrm{mg} / \mathrm{dL})$ & 37 & Free T4 (0.76-1.4 ng/dL) & 1.05 & Hemoglobin (13-17.5 g/dL) & 15.1 \\
\hline Uric acid (3.5-7.2 mg/dL) & 4.17 & Thyroid-stimulating hormone $\mathrm{SH}(0.35-4.5 \mu \mathrm{IU} / \mathrm{mL})$ & 0.77 & Hematocrit (40-52\%) & 44.2 \\
\hline Creatinine $(0.84-1.25 \mathrm{mg} / \mathrm{dL})$ & 0.89 & Anti-thyroid peroxidase ( $\leq 10 \mathrm{IU} / \mathrm{mL})$ & $<10$ & White blood cell (3.8-10 103/uL) & 7.15 \\
\hline Total cholesterol (0-200 mg/dL) & 178 & Anti-Tiroglobulin ( $\leq 20 \mathrm{IU} / \mathrm{mL}$ ) & $<20$ & Platelet (150-400 103/uL) & 210 \\
\hline Triglyceride $(0-150 \mathrm{mg} / \mathrm{dL})$ & 210 & Follicle-stimulating hormone (1.4-18.1 mIU/mL) & 40.01 & Erythrocyte sedimentation rate $(6-12 \mathrm{~mm} / \mathrm{h})$ & 7 \\
\hline High-density lipoprotein (40-85 mg/dL) & 49 & Luteinizing hormone (1.5-9.3 mlU/mL) & 28.92 & & \\
\hline Low-density lipoprotein (80-120 mg/dL) & 87 & Estradiol $(11.6-41.2 \mathrm{pg} / \mathrm{mL})$ & $<7$ & C-reactive protein $(0-3 \mathrm{mg} / \mathrm{L})$ & 1.96 \\
\hline Aspartate aminotransferase $(0-35 \mathrm{U} / \mathrm{L})$ & 30 & Testosterone (241-827 ng/dL) & 71.4 & & \\
\hline Alanine aminotransferase $(0-45 \mathrm{U} / \mathrm{L})$ & 50 & Sex hormone-binding globulin (13-71 nmol/L) & 35.7 & Microalbumin/creatine ratio (0-30 mg/gr) & 3.94 \\
\hline Gamma-glutamyltransferase (0-55 U/L) & 25 & Prolactin $(2.1-17.7 \mathrm{ng} / \mathrm{mL})$ & 3.94 & & \\
\hline Lactate dehydrogenase $(0-248 \mathrm{U} / \mathrm{L})$ & 202 & Cortisol $(4.3-22.4 \mu \mathrm{g} / \mathrm{dL})$ & 20.19 & & \\
\hline Alkaline phosphatase (30-120 U/L) & 67 & Adrenocorticotropic hormone $(0-46 \mathrm{pg} / \mathrm{mL})$ & 14.3 & & \\
\hline Total protein $(6.6-8.3 \mathrm{~g} / \mathrm{dL})$ & 7.69 & Dehydroepiandrosterone sulfate $(80-560 \mu \mathrm{g} / \mathrm{dL})$ & 65.2 & & \\
\hline Albumin $(3.5-5.2 \mathrm{~g} / \mathrm{dL})$ & 4.49 & Growth hormone (0-1 ng/mL) & 0.39 & & \\
\hline Sodium (136-146 mmol/L) & 138 & Parathyroid hormone (11.1-79.5 pg/mL) & 21.1 & & \\
\hline Potassium $(3.5-5.1 \mathrm{mmol} / \mathrm{L})$ & 4.38 & Connecting-peptide $(1.1-5.0 \mathrm{ng} / \mathrm{mL})$ & 2.85 & & \\
\hline Chloride (98-106 mmol/L) & 102 & Prostate-specific antigen (PSA) $(0-4 \mathrm{ng} / \mathrm{mL})$ & 0.21 & & \\
\hline Calcium $(8.8-10.6 \mathrm{mg} / \mathrm{dL})$ & 10.23 & Free PSA/PSA $(>0.2)$ & 0.52 & & \\
\hline Phosphorus (2.5-4.5 mg/dL) & 3.23 & & & & \\
\hline Glycated hemoglobin (4.2-6.5\%) & 14.9 & & & & \\
\hline
\end{tabular}

rascrotal testes smaller than physiological limits for normal [right testis: $13 \times 7 \times 15 \mathrm{~mm}(0.7 \mathrm{cc})$ and left testis $12 \times 7 \times 19 \mathrm{~mm}(0.8 \mathrm{cc})]$. Semen analysis disclosed presence of azoospermia. Thyroid function test results were within normal limits as follows: thyroid-stimulating hormone (TSH): $0.77 \mathrm{ulU} / \mathrm{mL}$ (range: $0.35-4.5 \mathrm{ulU} / \mathrm{mL}$ ), free T3 (FT3): $3.06 \mathrm{pg} /$ $\mathrm{mL}$ (range: $2.3-4.2 \mathrm{pg} / \mathrm{mL}$ ), free T4 (FT4): $1.05 \mathrm{ng} / \mathrm{dL}$ (range: $0.76-1.4 \mathrm{ng} / \mathrm{dL}$ ), and anti-thyroid peroxidase (anti-TPO): $<10 \mathrm{IU} / \mathrm{mL}(\leq 10 \mathrm{IU} / \mathrm{mL})$, and anti-tiroglobulin (anti-TG): $<20 \mathrm{IU} / \mathrm{mL}(\leq 20 \mathrm{IU} / \mathrm{mL})$. Patient was evaluated for microvascular complications of diabetes. Renal function test results were within reference ranges [urea: $37 \mathrm{mg} / \mathrm{dL}$ (range: $17-43 \mathrm{mg} / \mathrm{dL}$ ), creatinine $(\mathrm{Cr}$ ): $0.89 \mathrm{mg} / \mathrm{dL}$ (range: $0.84-1.25 \mathrm{mg} /$ $\mathrm{dL}$ ), and microalbumin/creatinine ratio in spot urine: $2.85 \mathrm{mg} / \mathrm{gr}$ (range: $30-300 \mathrm{mg} / \mathrm{gr}$ )], which ruled out nephropathy. Examination of optic fundus did not demonstrate any evidence of diabetic retinopathy. Patient did not describe any clinical symptom suggesting neuropathy and his neurological examination findings were within physiological limits. His free to total prostate-specific antigen (f/t PSA) ratio $(0.52)$ was not pathological.

Testosterone replacement therapy (50 mg gel $2 \times \mathrm{l}$ ) was initiated. At follow-up visits, insulin requirement decreased (I U/kg; $60 \mathrm{U} / \mathrm{d}$ ), and glycemic control was achieved. Eight weeks later, HbAlc was $7.7 \%$ (Figure 2). Written, informed consent was obtained from the patient.

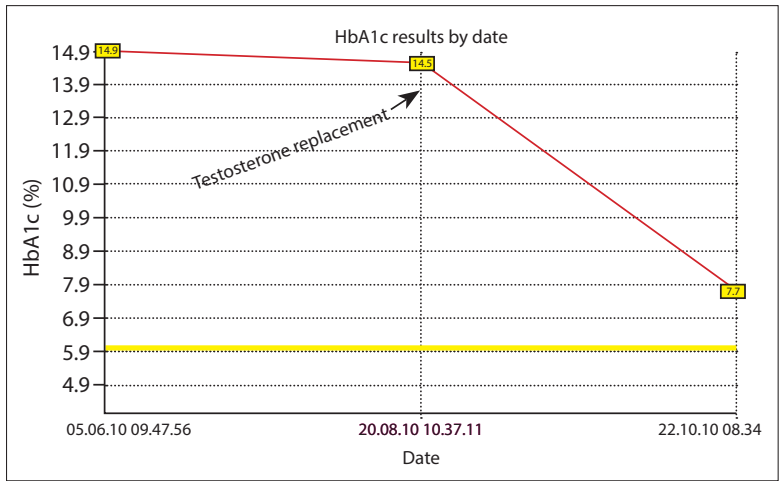

Figure 2. Insulin dose of patient with glycated hemoglobin (HbA1c) value of 14.9 who had been using insulin at daily dose of 80 units was reduced to 60 units per day after testosterone replacement therapy, and after 8 weeks, $\mathrm{HbA} 1 \mathrm{c}$ was measured at $7.7 \%$.

\section{DISCUSSION}

$\mathrm{KS}$ is the most frequently encountered sex chromosome disorder in men, with a prevalence of 1/660. Hypogonadism is the most widespread cause of male infertility and is often accompanied by learning disabilities. Classic features of men with KS included tall height, narrow shoulders, wide hips, and disproportional body parts (eunuchoid habitus), minimal facial and pubic hair, small and hard testes, micropenis, gynecomastia, mild to moderate levels of cognitive disorders, and hypergonadotropic hypogonadism. ${ }^{[5]}$ Now, however, incompleteness of this classic definition has been recognized, and it is known that patients with KS demonstrate a wide spectrum of phenotypi- 
cal manifestations. Syndrome also occurs across all of society. ${ }^{[6]}$ Therefore, in many male patient diagnosis of KS is overlooked. In a study performed in Denmark, authors demonstrated that nearly $25 \%$ of the patients with $\mathrm{KS}$ could be diagnosed. ${ }^{[7]}$ Adult KS patients really share only a few characteristics of the syndrome, such as elevated $\mathrm{LH}$ and $\mathrm{FSH}$, azoospermia, and small testes. ${ }^{[8]}$

In Western countries, incidence of diabetes in patients with $\mathrm{KS}$ has been reported as $15 \%$ to $50 \%{ }^{[9-11]}$ In this syndrome, type and severity of diabetes may differ, and many factors may contribute to development of diabetes. Insulin resistance is an important component of diabetes in this syndrome. Genetic factors, autoimmune mechanisms, and hormonal disorders have been suggested in pathogenesis of diabetes seen in KS. Incidence of leg ulcers, osteopenia, osteoporosis, and some tumors (e.g., breast, germ cell tumors) increases in patients with this syndrome. ${ }^{[12,13]}$ Men with KS are also at risk for autoimmune diseases, such as systemic lupus erythematosus. ${ }^{[14,15]}$

One of the components of KS, hypogonadism, can lead to development of abdominal obesity, which may then have well-known consequences of development of metabolic syndrome and insulin resistance. Abdominal obesity may also lead to lower testosterone levels. ${ }^{[5]}$ In other words, hypogonadism can contribute to development of metabolic syndrome and diabetes by inducing changes in distribution of body fat. However, diabetes, and metabolic syndrome per se, can trigger development of hypogonadism secondary to increased body weight, decreased SHBG level, and suppression of gonadotropin release and testosterone production. ${ }^{[16]}$ Diabetes and metabolic syndrome are associated with increased levels of some cytokines, including interleukin-I beta (IL-I $\beta$ ), IL-6, and tumor necrosis factor-alpha, which can depress steroidogenesis and production of testosterone. ${ }^{[17-19]}$ Both of these scenarios can contribute partially or completely to this vicious cycle.

Hormonal disorders, such as hyperestrogenism, increase in estrogen/testosterone ratio (responsible for gynecomastia), and delay in increase in testosterone level during puberty, are responsible for characteristic body habitus of KS. ${ }^{[20]} \mathrm{It}$ is not known whether morbidities associated with syndrome are consequences of hypogonadism and hyperestroge- nism, or if they manifest as a result of dysfunction of genes related to $X$ chromosome.

In men with KS and those with normal karyotype, hypogonadism is an independent risk factor for abdominal adiposity. ${ }^{[2]}$ In cross-sectional studies, increased incidence of hypogonadism has been reported in diabetic men. ${ }^{[1,22,23]}$ In a study performed in the USA, prevalence of hypotestosteronemia $(<300 \mathrm{ng} / \mathrm{dL})$ was $38.7 \%$ in 2162 men aged $\geq 45$ years who presented at primary healthcare clinics. Increased incidence of hypogonadism has been demonstrated both in obese (2.4-fold) and diabetic (2.I-fold) men. ${ }^{[24]}$

Hypergonadotropic or hypogonadotropic hypogonadism induces insulin resistance in men irrespective of etiology. ${ }^{[25]}$ Testosterone levels are inversely correlated with $\mathrm{HbAlc}$ levels. In other words, $\mathrm{HbAlc}$ levels are markedly elevated at lowest testosterone levels. ${ }^{[26]}$

Despite close relationship between hypogonadism and diabetes, very few studies have investigated effects of androgen replacement treatment on diabetes. One is a double-blind, placebo-controlled study conducted by Kapoor et al. In this study of 24 men with type 2 diabetes and hypogonadism, testosterone replacement therapy increased insulin sensitivity and induced marked reductions in $\mathrm{HbAlc}(0.37 \pm 0.17 \%)$, fasting blood glucose level, waist circumference, and waist/hip ratio. ${ }^{[27]}$

In placebo-controlled meta-analysis of 5 studies performed by Cai et al. in 2014, which included the study of Kapoor et al., effects of testosterone replacement treatment on patients with diagnosis of hypogonadism and type 2 diabetes were evaluated in $35 \mathrm{I}$ participants. Patients were followed-up for an average of 6.5 months. Testosterone replacement treatment in type 2 diabetes patients was shown to improve glycemic control and decrease triglyceride levels. ${ }^{[28]}$

In summary, incidence of diabetes increases in KS. Hypoandrogenemia associated with syndrome contributes to development of de novo diabetes and worsening of pre-existing diabetes. However, whether or not any chromosomal anomaly is present in diabetic patients, generally, treatment of hypogonadism, which can be associated with diabetes, has been overlooked. This case report has demonstrated very important role of testos- 


\section{terone replacement in achievement of glycemic control.}

\section{Conflict of interest \\ None declared.}

\section{REFERENCES}

1. Klinefelter HF, Reifenstein EC, Albright F. Syndrome characterized by gynecomastia, spermatogenesis without A-Leydigism, and increased secretion of follicle-stimulating hormone. J Clin Endocrinol 2 1942;615-27.

2. Kleczkowska A, Fryns JP, Van den Berghe H. X-chromosome polysomy in the male. The Leuven experience 1966-1987. Hum Genet 1988;80:16-22.

3. Nielsen J, Wohlert M. Chromosome abnormalities found among 34,910 newborn children: results from a 13-year incidence study in Arhus, Denmark. Hum Genet $1991 ; 87: 81-3$.

4. Bojesen A, Kristensen K, Birkebaek NH, Fedder J, Mosekilde L, Bennett $\mathrm{P}$, et al. The metabolic syndrome is frequent in Klinefelter's syndrome and is associated with abdominal obesity and hypogonadism. Diabetes Care 2006;29:1591-8.

5. Bojesen A, Høst C, Gravholt CH. Klinefelter's syndrome, type 2 diabetes and the metabolic syndrome: the impact of body composition. Mol Hum Reprod 2010;16:396-401.

6. Lanfranco F, Kamischke A, Zitzmann M, Nieschlag E. Klinefelter's syndrome. Lancet 2004;364:273-83.

7. Bojesen A, Juul S, Gravholt CH. Prenatal and postnatal prevalence of Klinefelter syndrome: a national registry study. J Clin Endocrinol Metab 2003;88:622-6.

8. Smyth CM, Bremner WJ. Klinefelter syndrome. Arch Intern Med 1998;158:1309-14.

9. Nielsen J, Johansen K, Yde H. Frequency of diabetes mellitus in patients with Klinefelter's syndrome of different chromosome constitutions and the XYY syndrome. Plasma insulin and growth hormone level after a glucose load. J Clin Endocrinol Metab 1969;29:1062-73.

10. Becker KL, Hoffman DL, Underdahl LO, Mason HL. Klinefelter's syndrome. Clinical and laboratory findings in 50 patients. Arch Intern Med 1966;118:314-21.

11. Forbes AP, Engel E. The high incidence of diabetes mellitus in 41 patients with gonadal dysgenesis, and their close relatives. Metabolism 1963;12:428-39.

12. Seo JT, Lee JS, Oh TH, Joo KJ. The clinical significance of bone mineral density and testosterone levels in Korean men with non-mosaic Klinefelter's syndrome. BJU Int 2007;99:141-6.

13. Rovenský J. Rheumatic diseases and Klinefelter's syndrome. Autoimmun Rev 2006;6:33-6.

14. Takeuchi Y, Murata Y, Sintani J, Masukawa H, Nakamura R, Oi K, et al. Klinefelter's syndrome accompanied by mixed connective tissue disease and diabetes mellitus.
Intern Med 1999;38:875-81.

15. Aoki N. Klinefelter's syndrome, autoimmunity, and associated endocrinopathies. Intern Med. 1999;38:838-9.

16. Kalyani RR, Dobs AS. Androgen deficiency, diabetes, and the metabolic syndrome in men. Curr Opin Endocrinol Diabetes Obes 2007;14:226-34.

17. Chen RY, Wittert GA, Andrews GR. Relative androgen deficiency in relation to obesity and metabolic status in older men. Diabetes Obes Metab 2006;8:429-35.

18. Giulietti A, Stoffels K, Decallonne B, Overbergh L, Mathieu C. Monocytic expression behavior of cytokines in diabetic patients upon inflammatory stimulation. Ann N Y Acad Sci 2004;1037:74-8.

19. de Rekeneire N, Peila R, Ding J, Colbert LH, Visser M, Shorr RI, et al. Diabetes, hyperglycemia, and inflammation in older individuals: the health, aging and body composition study. Diabetes Care 2006;29:1902-8.

20. Hsueh WA, Hsu TH, Federman DD. Endocrine features of Klinefelter's syndrome. Medicine (Baltimore) 1978;57:447-61.

21. Tsai EC, Boyko EJ, Leonetti DL, Fujimoto WY. Low serum testosterone level as a predictor of increased visceral fat in Japanese-American men. Int J Obes Relat Metab Disord 2000;24:485-91.

22. Zitzmann M, Faber S, Nieschlag E. Association of specific symptoms and metabolic risks with serum testosterone in older men. J Clin Endocrinol Metab 2006;91:4335-43.

23. Kapoor D, Malkin CJ, Channer KS, Jones TH. Androgens, insulin resistance and vascular disease in men. Clin Endocrinol (Oxf) 2005;63:239-50.

24. Mulligan T, Frick MF, Zuraw QC, Stemhagen A, McWhirter C. Prevalence of hypogonadism in males aged at least 45 years: the HIM study. Int J Clin Pract 2006;60:762-9.

25. Oh JY, Barrett-Connor E, Wedick NM, Wingard DL; Rancho Bernardo Study. Endogenous sex hormones and the development of type 2 diabetes in older men and women: the Rancho Bernardo study. Diabetes Care 2002;25:55-60.

26. Svartberg J, Jenssen T, Sundsfjord J, Jorde R. The associations of endogenous testosterone and sex hormonebinding globulin with glycosylated hemoglobin levels, in community dwelling men. The Tromsø Study. Diabetes Metab 2004;30:29-34.

27. Kapoor D, Goodwin E, Channer KS, Jones TH. Testosterone replacement therapy improves insulin resistance, glycaemic control, visceral adiposity and hypercholesterolaemia in hypogonadal men with type 2 diabetes. Eur J Endocrinol 2006;154:899-906.

28. Cai X, Tian Y, Wu T, Cao CX, Li H, Wang KJ. Metabolic effects of testosterone replacement therapy on hypogonadal men with type 2 diabetes mellitus: a systematic review and meta-analysis of randomized controlled trials. Asian J Androl 2014;16:146-52. 


\section{Klinefelter Sendromu ve Kötü Kontrollü Diyabeti Olan Bir Olguda Androjen Replasman} Tedavisinin Kan Şekeri Regülasyonu Üzerine Etkileri

Hipergonadotropik hipogonadizm ve önikoid vücut yapısı ile karakterize olan Klinefelter sendromu (KS), erkeklerde en sık rastlanan seks kromozom anomalisi olup, genellikle 47,XXY karyotipine sahiptir. Klinefelter sendromunda, otoimmün hastalık ve diyabet gelişme riskinin yüksek olduğu ve eşlik eden hipoandrojeneminin diyabet regülasyonunu kötüleştirdiği çalışmalarda gösterilmiştir. Otuz dokuz yaşındaki erkek hasta, kan şekeri yüksekliği nedeniyle endokrinoloji ve metabolizma hastalıkları polikliniğine başvurdu. Yaklaşık beş yıldır diyabet tanısı olan hastanın $\mathrm{HbAlc}$ değeri \% 14.9 olarak belirlendi. Başvuru sırasında günlük yaklaşık 80 ünite insülin kullanan hastanın androjen replasman tedavisi sonrası insülin ihtiyacı yaklaşık 60 üniteye kadar geriledi. Takiplerinde, androjen replasman tedavisi başlandıktan iki ay sonraki kontrol $\mathrm{HbAlc}$ değeri \%7.7 olarak belirlendi. Hipoandrojenemi diyabet gelişimi ve mevcut diyabetin regülasyonunda bozulmaya sebep olmaktadır. Bu hastalarda testosteron replasmanı, glisemik kontrolü düzeltebilir.

Anahtar Sözcükler: Androjen replasman tedavisi; diyabetes mellitus; Klinefelter sendromu. 